\title{
Floating photovoltaic system for Indian artificial reservoirs-an effective approach to reduce evaporation and carbon emission
}

\author{
N. Ravichandran ${ }^{1} \cdot$ N. Ravichandran ${ }^{2}\left(\mathbb{D} \cdot\right.$ B. Panneerselvam ${ }^{3}$
}

Received: 27 February 2021 / Revised: 21 August 2021 / Accepted: 20 September 2021 / Published online: 6 October 2021

(c) The Author(s) 2021

\begin{abstract}
Floating photovoltaic system for reservoirs is a recent innovative technology that is highly advantageous in reducing evaporation while generating solar power. In addition, the integration of floating photovoltaic systems with the existing hydroelectric power plants will increase renewable power production. The present study aims to assess the electrical performance of floating photovoltaic systems in major reservoirs with existing hydroelectric power plants in India. The reservoirs with large water surface area were selected for the study, and a model floating photovoltaic system with a 5-MW capacity was designed for the selected reservoirs. The numerical analysis showed that installing floating photovoltaic systems will result in an annual energy yield of $160 \mathrm{GWh}$. Further, the systems also save 1.40 million cubic meters of water per day and also help in generating additional energy of $514.80 \mathrm{MWh}$ /day from the saved water through its integration with hydroelectric power plants. A single-axis tracking mechanism to the floating photovoltaic systems will increase the annual energy generation by $11 \%$. The detailed cost analysis and carbon emission analysis were also carried out. The results indicate that the tracking mechanisms increase the total installation cost of the systems. The annual carbon emission reduction from the floating photovoltaic systems accounts for about 3.30 million tons of $\mathrm{CO}_{2}$. The obtained results highlight the suitability of this innovative technology for installation in Indian reservoirs and its effectiveness in reducing evaporation and carbon emission.
\end{abstract}

Editorial Responsibility: Samareh Mirkia.

N. Ravichandran

vino.civil35@gmail.com

1 Department of Electrical Engineering and Information Technologies, University of Naples Federico II, Naples, Italy

2 Department of Structures for Engineering and Architecture, University of Naples Federico II, Naples, Italy

3 Department of Civil, Building and Environmental Engineering, University of Naples Federico II, Naples, Italy 


\section{Graphic abstract}

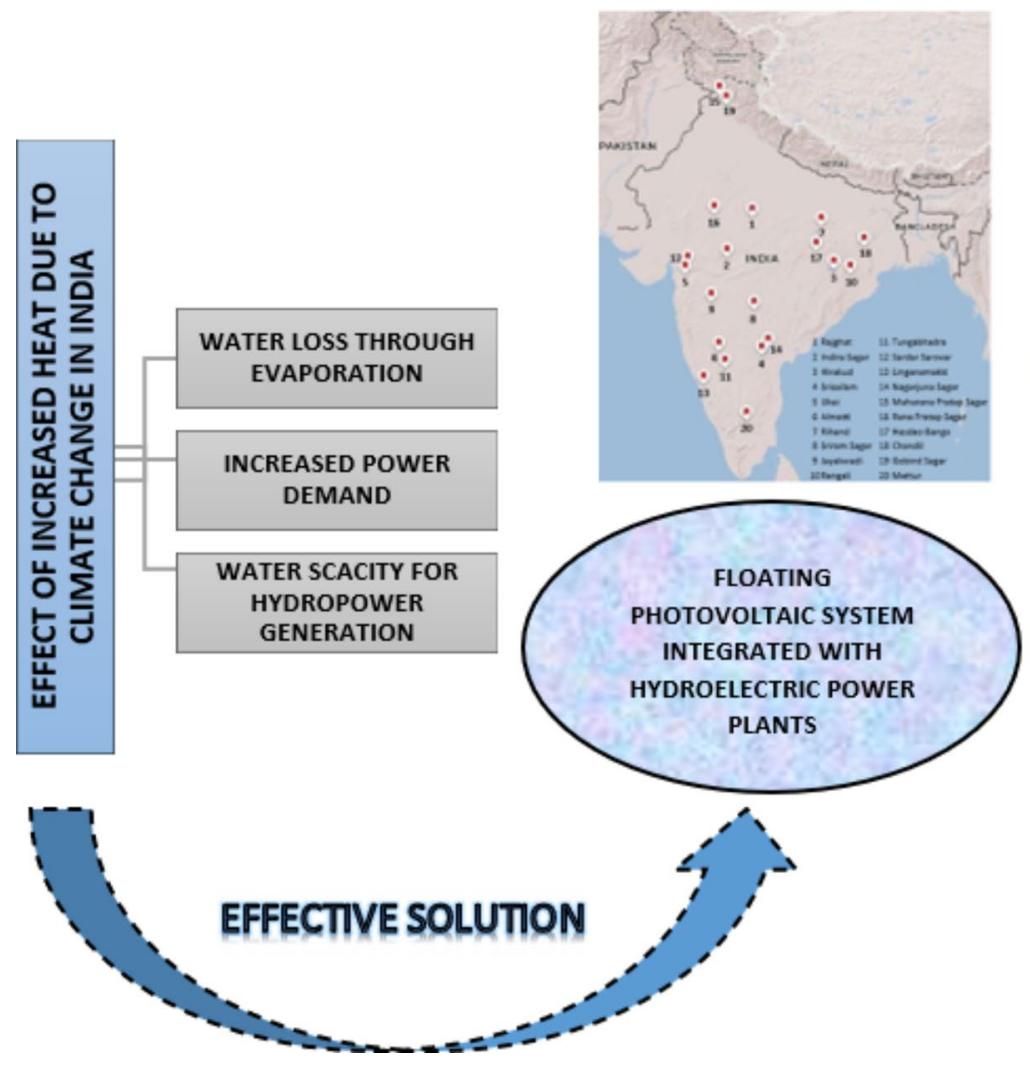

\section{Floating photovoltaic system for Indian artificial reservoirs - An effective approach to reduce evaporation and carbon emission}

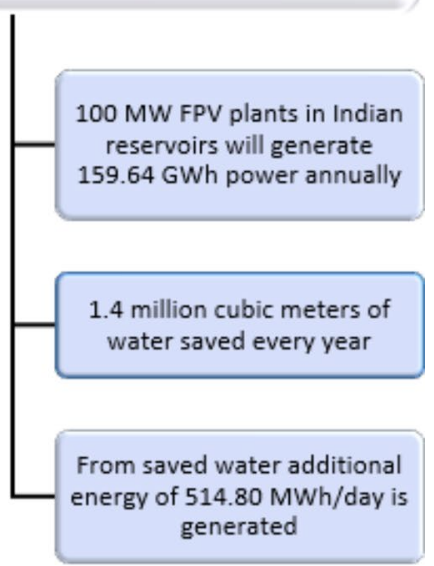

Keywords Evaporation loss $\cdot$ Floatovoltaics $\cdot$ Hydroelectric power plants $\cdot$ Renewable energy $\cdot$ Solar energy

\author{
Abbreviations \\ BoS Balance-of-system \\ $\mathrm{CO}_{2} \quad$ Carbon dioxide \\ CSP Concentrated solar power \\ FPV Floating photovoltaic \\ FPCS Floating photovoltaic cover system \\ GHI Global horizontal irradiation \\ GW Gigawatt \\ HDPE High-density polyethylene \\ HEPP Hydroelectric power plant \\ INDC Intended nationally determined contributions \\ MW Mega-watt \\ NASA National Aeronautics and Space Administration \\ PET Potential evapotranspiration \\ POA Plane of array \\ PR Performance ratio \\ PV Photovoltaic \\ RES Renewable energy sources \\ SEC Specific electricity consumption \\ TMY Typical metrological year
}

\section{Introduction}

Until the last decade, the primary source of power generation is fossil fuels, which lead to enormous carbon emissions that adversely affect the environment (IEA 2021). Industrialization and increase in population led to the fast depletion of fossil fuels in recent years and resulted in the exponential rise in energy demand. It has been predicted that the global energy demand will increase by $50 \%$ in the next thirty years (Trapani and Millar 2013). This highlights the necessity for sustainable energy production with reduced carbon emission through renewable energy solutions using solar, wind, tidal, and hydropower sources. The world nations are also prioritizing the research and development in the field of renewable energy, which resulted in $181 \mathrm{GW}$ of renewable energy production in 2018 by increasing the global renewable power production to $2378 \mathrm{GW}$. Further, a reduction in the use of fossil fuels and nuclear power has also been noticed due to the increase in renewable energy production. Studies also estimated that renewable energy has the potential to provide $27.3 \%$ of global 
electricity. In particular, renewable energy production in India accounts for about $21.4 \%$ of the global electricity generation. India stands fourth in renewable power investments and third in solar energy installations (IRENA 2019). The growth India's renewable power industry is remarkable and has made a significant contribution to reducing carbon emissions. Considering the noteworthy improvements in renewable energy, studies on the suitability of innovative renewable energy technologies are necessary to improve energy production further.

India plays a significant role in promoting the installation of solar-based energy production globally and increased the country's installed capacity by more than $11 \%$ in the last five years (Murdock et al. 2021). The total installed solar photovoltaic (PV) capacity in India is $33.73 \mathrm{GW}$ from the roof-mounted PV systems, 27.93 GW from the ground-mounted PV systems, and $0.92 \mathrm{GW}$ from offshore PV plants. According to the new renewable resources report by the Indian government, the gross electricity generated from the solar PV sector is 39268 GWh in 2019 (MNRE 2019). The suitable irradiation level and 300 average clear sunny days in India are the major motivation for the increasing solar PV installations (Jain et al. 2011).

One of the recent innovations in solar power production is the installation of floating photovoltaic (FPV) panels in the water bodies (Ranjbaran et al. 2019; Sahu et al. 2016). The FPV system is the method of positioning the solar PV modules on the deck, which has enough buoyancy to float itself on the water storage structures such as lakes, ponds, and reservoir and wastewater basins. In addition to power generation, installing FPV systems in open reservoirs will also reduce evaporation by covering the water surface area from direct sunlight. The total installed capacity of FPV systems worldwide had reached 505 GW in 2018 (Gorjian et al. 2020). The largest installed capacity of the FPV system in the world is $150 \mathrm{MW}$ in the region of Anhui, China (Nagananthini et al. 2020). In India, the first FPV system was installed in 2015 with a capacity of $10 \mathrm{~kW}$. At present, the 2-MW FPV plant in Vishakhapatnam is India's largest FPV system in operation. India considers FPV as the third pillar of solar technology and aims at continuously increasing the cumulative installed capacity of the FPV systems. With $18,000 \mathrm{~km}^{2}$ of water surface area, India can hold FPV systems up to $250 \mathrm{GW}$ capacity (Acharya and Devraj 2019).

Despite the availability of enormous water bodies, India faces acute water shortages during summer. Water scarcity remains a persistent problem in several regions of the country, even throughout the year. This can be attributed to the loss of stored water from the reservoirs by evaporation due to the hot and dry daytime temperature in summer (Krishnan et al. 2020; Rao et al. 2012). A suitable structural system or methodology to reduce water evaporation is necessary to overcome drought conditions. However, the design and installation of systems solely to minimize water evaporation in open reservoirs are not cost-effective, especially for a developing nation like India. In this context, FPV systems can be an effective solution to avoid evaporation while producing solar power. Several studies reported the effectiveness of the FPV systems in reducing the evaporation up to $90 \%$ through experimental and analytical investigations (Azami et al. 2017; Liu et al. 2017; Lopes et al. 2020; Mckay 2013; Mittal et al. 2017; Nagananthini and Nagavinothini 2021; Nazififard et al. 2017; Ravichandran et al. 2021; Rosa-Clot et al. 2017; Santafé et al. 2014; Taboada et al. 2017). The significant observations in terms of installed capacity and water-saving effect of the FPV plants from the literature are outlined in Table 1.

An additional advantage of the FPV system is the possible combination of the FPV plants with the hydroelectric power plants (HEPPs) in the reservoirs. Recent studies reported that the combination of renewable technologies had resulted in a higher energy yield (Cazzaniga 2020; Lee et al. 2020; Nagananthini and Nagavinothini 2021; Rosa-clot and Tina 2020). In India, the installed capacity of HEPP is about $44.95 \mathrm{GW}$, which accounts for $13.50 \%$ of the nation's total power generation capacity (MNRE 2019). Thus, hybridizing these renewable energy sources
Table 1 Comparison of installed capacity and watersaving effect of FPV systems

\begin{tabular}{lllll}
\hline Sl. no. & Location of FPV plant & $\begin{array}{l}\text { Installed } \\
\text { capacity } \\
\text { (MW) }\end{array}$ & $\begin{array}{l}\text { Area of cover- } \\
\text { age of FPV (\%) }\end{array}$ & $\begin{array}{l}\text { Water- } \\
\text { saving }\left(\mathrm{m}^{3} /\right. \\
\text { year) }\end{array}$ \\
\hline 1 & Mettur Reservoir, India (Ravichandran et al. 2021) & 3.5 & 30 & $1.8 \times 10^{5}$ \\
2 & Vaigai Reservoir, India & 1.0 & 30 & $4.3 \times 10^{4}$ \\
& (Nagananthini and Nagavinothini 2021) & & & $4.2 \times 10^{9}$ \\
3 & Mossoro basin, Brazil (Lopes et al. 2020) & $1.20 \times 10^{6}$ & 70 & $2.0 \times 10^{27}$ \\
4 & China (Liu et al. 2017) & $1.60 \times 10^{5}$ & 2 & $5.5 \times 10^{8}$ \\
5 & Kishore Sagar lake, India (Mittal et al. 2017) & 1.0 & 20 & $2.5 \times 10^{4}$ \\
6 & South Australia (Rosa-Clot et al. 2017) & 9.4 & 100 &
\end{tabular}


through the implementation of FPV in the reservoirs with inbuilt HEPP will result in additional advantages in terms of reduced cost, water savings, existing infrastructure for grid connection, and possibilities of intermittent power operation (Cazzaniga et al. 2018; Ravichandran et al. 2021). Land acquisition for large-scale implementation of $\mathrm{PV}$ plants is becoming a persistent problem in rural agricultural and urban residential areas. Also, it is essential to note that the global HEPP installed capacity has reached its maximum level. In this context, FPV can be seen as an efficient solution that eliminates the power deterring factors in both renewable power generators. Further, additional factors such as reduced soiling loss and automated water evaporative cooling make FPV more efficient than land- and roof-mounted PV systems.

The performance and installation potential of the FPV system depend on the percentage of water area covered, water-level fluctuations, the purpose of the reservoir, and the location of the proposed plant (Haas et al. 2020). Hence, the installation of FPV plants in reservoirs is highly beneficial when compared to that of lakes. Further, the dams with HEPP will benefit from using the water saved from evaporation for hydropower generation. The increase in hydropower generation due to the hybridization of HEPP with FPV plants has also been reported in the literature (Farfan and Breyer 2018; Lopes et al. 2020). However, detailed studies on the suitability of this novel technology in India, with specific attention to hybrid FPVHEPP systems, are scarce in the literature. Few studies had reported the performance analysis of model FPV systems in specific dams in India (Nagananthini and Nagavinothini 2021; Ravichandran et al. 2021). But the large-scale performance analysis covering the entire nation to highlight the chances of potential improvement in solar power production in India is not available.

The aim of the present study is to assess the performance of FPV plants as a covering system for Indian reservoirs to reduce evaporation and the possibility of hybrid FPV-HEPP systems in India. Initially, 20 Indian reservoirs with the largest water surface area and inbuilt HEPPs were selected for the study. A preliminary design of a 5-MW model FPV plant was carried out for all the selected reservoirs. The numerical models of the demonstrative FPV plants were developed using HelioScope, and detailed numerical analyses were then carried out to assess the electrical performance of the systems. The carbon footprint and economic analysis of the FPV systems were also carried out to investigate the additional benefits of the system. The annual energy yield, water, and land-saving effects are reported, and improved power generation capacity of HEPP by utilizing the saved water from evaporation through FPV implementation is also discussed. With the fast-growing solar energy installations in India, the results presented in this study will positively contribute to the solar sector in selecting the location for installation and preliminary design of FPV systems.

The main scope of the present study is to investigate the influence of hybrid FPV plant installation on the annual evaporation and carbon emission in India. This investigation focused on India can be seen as an important contribution to the sustainable growth of power generation in the nation with arid or semiarid climate conditions coupled with high irradiation levels. Concerning the meteorological and geographical conditions of the country, the proposed solution using FPV covering system will use available irradiation to produce solar power, combat water evaporation, and reduce carbon emission. The novelty of the study lies in the comprehensive analysis of the novel FPV systems in major reservoirs in India and the detailed assessment of their positive effect on the environment. This multidisciplinary study focused on the electrical, structural, and environmental aspects of the innovative FPV systems is carried out by a team of researchers from India and Italy from September 2020 to February 2021.

\section{Need for FPV system-A hybrid power source solution to India}

The climate of India is the tropical monsoon type divided into winter, summer, southwest, and northeast monsoon. The increase in temperature and seasonal variations in recent years increases the evaporation rate of freshwater sources. According to the report released by the National Aeronautics and Space Administration (NASA), the National Oceanic and Atmospheric Administration (NOAA), and the United Kingdom meteorological office, the year 2019 was recorded as the second hottest year of the decade, during which most of the cities in India had faced acute water scarcity. According to the Centre for Climate Change Research, the average temperature increase in India is estimated to be approximately $4.4{ }^{\circ} \mathrm{C}$ (Krishnan et al. 2020). With this continuous temperature rise, the need to preserve water during monsoon seasons becomes essential. The artificial reservoirs are meant to store the water at its availability during monsoon rainfall and utilize them during drought conditions. But the effect of temperature rise leads to wastage of water without being appropriately used (Panneerselvam et al. 2020, 2021). Every year, a massive amount of consumable water is wasted due to evaporation.

The amount of evaporation is usually assessed using potential evapotranspiration (PET). To determine the nominal evaporation rate in India, PET was calculated for 50 meteorological stations all over India using the available meteorological data from 1981 to 2020 . The PET 


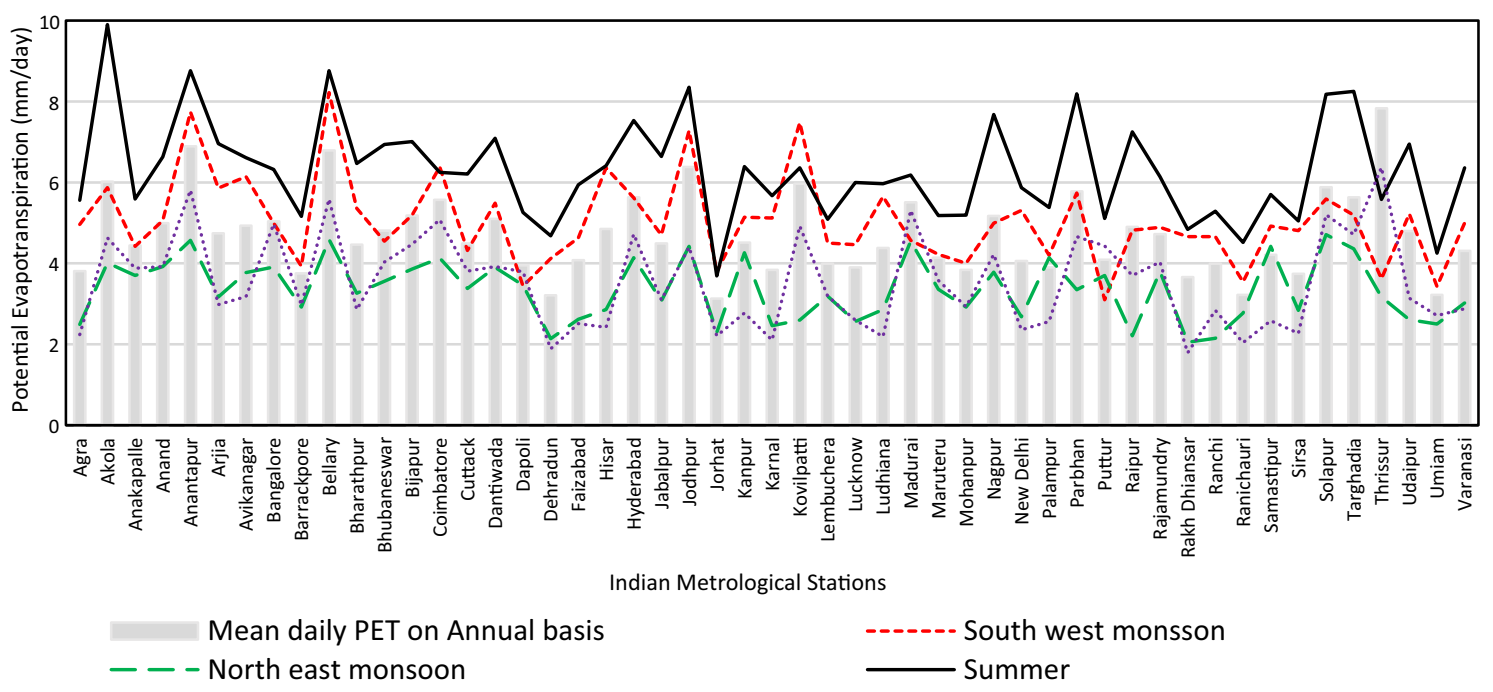

Fig. 1 Comparison of annual and seasonal potential evapotranspiration (PET) calculated by the Penman-Monteith method at the metrological stations all over India

rate was calculated using the Penman-Monteith method, the standard method for calculating the evaporation rate. The following expression was used to find the PET of the selected stations in India (Rao et al. 2012):

$E T_{o}=\frac{0.408 \Delta\left(R_{n}-G\right)+\gamma \frac{900}{T+273} u_{2}\left(e_{s}-e_{a}\right)}{\Delta+\gamma(1+0.34) u_{2}}$

where $E T_{o}$ is the reference evapotranspiration ( $\mathrm{mm} /$ day), $\Delta$ is the slope of the vapor pressure curve $\left(\mathrm{kPa}^{\circ} \mathrm{C}^{-1}\right), u_{2}$ is the wind speed at $2 \mathrm{~m}$ height $(\mathrm{m} / \mathrm{s}), R_{n}$ is the net radiation ( $\mathrm{MJm}^{-2} /$ day), $G$ is the soil heat flux density $\left(\mathrm{MJm}^{-2} /\right.$ day), $e_{s}$ is the saturation vapor pressure $(\mathrm{kPa}), e_{a}$ is the actual pressure $(\mathrm{kPa}), \gamma$ is psychometric constant $\left(\mathrm{kPa}^{\circ} \mathrm{C}^{-1}\right)$, and $T$ is the mean daily air temperature at $2 \mathrm{~m}$ height $\left({ }^{\circ} \mathrm{C}\right)$ (Penman 1948). The comparison of annual and seasonal potential PET from 1981 to 2020 in the 50 meteorological stations in India is shown in Fig. 1. The evapotranspiration rate is potentially high during summer in all meteorological stations, and it ranges from 3.69 to $9.90 \mathrm{~mm} /$ day. Due to the tropical climate in India, the minimum value of PET observed in the meteorological stations even during the winter season is $1.79 \mathrm{~mm} /$ day. This highlights the need to avoid evaporation and loss of water stored for irrigation and drinking purposes in open reservoirs throughout the year.

Several attempts have been made to identify an efficient solution to mitigate the freshwater loss due to evaporation, including covering the reservoirs with waterproof geomembrane such as floating covers, chemical monolayers, and water shades. Studies also reported the effectiveness of these techniques in reducing evaporation by $80 \%$ (Craig et al. 2005). The recent innovation in transforming the covering material with FPV panels will help in reducing the evapotranspiration and also provides additional electricity (Ferrer-Gisbert et al. 2013; Kougias et al. 2016). This Floating Photovoltaic Covering System (FPCS) technique can provide solutions to both water and energy demands in highly populated developing nations like India. Studies state that covering $10 \%$ reservoir coverage by FPV systems will reduce evaporation by $6-18 \%$, and the power production can be increased up to $23 \%$. Further, the FPV system covering the entire reservoir surface has saved a thousand gallons of water annually, which is equivalent to $25 \%$ of the reservoir storage capacity (Santafe et al. 2014). The additional advantage of the FPV system is the reduction in land use for solar power generation. Even though the FPV installation does not use a water source as its energy vector, it is a medium to reduce the panel temperature, which helps in increasing the efficiency of the panels (Cazzaniga et al. 2018).

Existing FPV plants worldwide are installed in stagnant water bodies like ponds, lakes, and reservoirs to avoid excessive external forces on the floating platforms developed due to wave and wind action. Implementing FPV systems in moving water bodies such as rivers requires more resilient floating platforms capable of holding the PV arrays in position, adequately oriented at an optimum title angle. In addition, the abrupt change in the water depth of running water bodies also endangers the position restraining systems of the FPV plants. Due to the challenges associated with the stability and cost of such systems, FPV plants in moving water bodies are not highly advantageous compared to stagnant water bodies. Despite the challenges related to the wind, wave, and tidal action, FPV systems are being installed in offshore locations in recent years (Trapani and Miler 2013; Trapani and Santafe 2015). This 
Table 2 Power installation and generation capacity of HEPP and PV system (IRENA 2019)

\begin{tabular}{llllll}
\hline Year & HEPP & & & Solar \\
\cline { 2 - 3 } \cline { 6 - 6 } & $\begin{array}{l}\text { Installed } \\
\text { capacity } \\
\text { (MW) }\end{array}$ & $\begin{array}{l}\text { Electricity } \\
\text { generation } \\
(\mathrm{GW})\end{array}$ & & $\begin{array}{l}\text { Installed } \\
\text { capacity } \\
(\mathrm{MW})\end{array}$ & $\begin{array}{l}\text { Electricity } \\
\text { generation } \\
(\mathrm{GW})\end{array}$ \\
\hline 2010 & 35,866 & 107,176 & & 65 & 65 \\
2011 & 37,631 & 119,724 & & 563 & 305 \\
2012 & 38,250 & 128,145 & & 979 & 969 \\
2013 & 39,388 & 121,004 & & 1446 & 1600 \\
2014 & 40,621 & 135,865 & & 3444 & 2739 \\
2015 & 42,317 & 130,562 & & 5365 & 5619 \\
2016 & 42,838 & 125,211 & & 9651 & 9822 \\
2017 & 44,751 & 126,402 & & 17,923 & 17,768 \\
2018 & 45,296 & 131,650 & & 27,127 & 30,707 \\
2019 & 45,440 & 139,584 & & 34,831 & 49,657 \\
\hline
\end{tabular}

can be attributed to the current research advancements in designing highly reliable FPV systems suitable for harsh offshore environments.

\section{Effects of HEPP-FPV integration}

The capacity of installed solar and hydropower capacity is increasing steadily over the last ten years. The installed capacity and the amount of electricity generated from solar and hydroelectric power plants in India from 2010 to 2018 are listed in Table 2 . In the hydropower installation and electricity generation data, the output from the pumped hydroelectric power plants is excluded and thermal photovoltaic technology is not considered in the solar sector. The presented information is focused only on the HEPP in the reservoirs and ground or roof-mounted solar PV systems. The annual average increase in the installed capacity of HEPP and solar PV systems is $1.1 \mathrm{GW}$ and 3.9 GW, respectively. The tremendous growth in solar PV installations can be mainly observed after 2013 .

Despite the global market stability of hydropower technology, the increase in power generation capacity of HEPP installations is comparatively lower than that of solar and wind energy plants in recent years. This is due to the fact that the worldwide hydropower generation capacity of the reservoirs has already reached its maximum level. In addition, most HEPPs demand a modernized upgrade to enhance the total working hours to avoid frequent turbine faults of the aged components (Cazzaniga et al. 2019). The shift in recent technology in integrating variable sources of renewable energy such as solar, wind, and hydropower is the emerging solution in the global market to increase the renewable energy share in the power sector. In this context, the hybrid FPV-HEPP is more advantageous compared to stand-alone FPV systems or HEPPs.

The main advantages of the hybrid HEPP-FPV systems are the available grid connectivity, battery storage, and high efficiency compared to standalone PV systems (Gulagi et al. 2017). In addition, this integration of renewable power technologies aids in the intermittent operation of HEPP (Farfan and Breyer 2018). Intermittent operation refers to the utilization of power produced from the FPV system during high irradiation levels to match the grid requirements and to tune the hydroelectricity production when the radiation is not enough or absent. This helps in avoiding the turbine damages in HEPPs due to continuous operation. In addition, the saved water through evaporation reduction can be effectively used for hydropower generation. Hence, the integration of FPV plants and HEPPs will result in direct and indirect water-saving effects. The water saved through the reduction of evaporation is the direct water-saving effect. Since FPV systems are utilized as a substitute for HEPP to facilitate intermittent operation during peak hours, the equivalent water consumption by HEPP for generating the equal amount of electricity produced by FPV systems corresponds to the indirect watersaving effect (Liu et al. 2017).

Evaporation mitigation through the installation of FPV systems in open water reservoirs is directly proportional to the area of the FPV plant that covers the water surface. Complete covering of the reservoir water surface to increase power production through FPV systems obstructs the intrusion of sunlight. It may result in long-term impacts on the water quality and aquatic life. The reduction in short-wave radiation modifies the thermal stratification of the reservoir, which in turn affects the deep-water oxygen. FPV installation impacts marine aquaculture and alters the food web, fishing pattern, migratory bird habitats, and surface diving birds. In addition, the photodegradation of chemical compounds reduces the quality of water and increases the cost of water treatment. Thus, it is advisable to limit the percentage of covering to $25-30 \%$ of the total reservoir area (Acharya and Devraj 2019). To this end, the present study aims at presenting the advantages of this innovative technology, even with smaller coverage areas.

\section{Materials and methods}

\section{Indian reservoirs selected for the study}

A detailed numerical investigation of the model FPV systems in 20 reservoirs with HEPP throughout India was carried out in the present study to predict the advantages of 
Table 3 Largest reservoirs in India selected for the study

\begin{tabular}{|c|c|c|c|c|c|c|c|}
\hline Sl. no. & Reservoir & State & River & Latitude $(\mathrm{N})$ & Longitude (E) & $\begin{array}{l}\text { Total surface } \\
\text { area }\left(\mathrm{km}^{2}\right)\end{array}$ & $\begin{array}{l}\text { Installed capacity } \\
\text { of HEPP (MW) }\end{array}$ \\
\hline 1 & Rajghat & Uttar Pradesh & Betwa & $24^{\circ} 45^{\prime} 47^{\prime \prime}$ & $78^{\circ} 13^{\prime} 57^{\prime \prime}$ & 2453.00 & 45.00 \\
\hline 2 & Indira Sagar & Madhya Pradesh & Narmada & $22^{\circ} 17^{\prime} 03^{\prime \prime}$ & $76^{\circ} 28^{\prime} 17^{\prime \prime}$ & 913.48 & 1000.00 \\
\hline 3 & Hirakud & Odisha & Mahanadi & $21^{\circ} 32^{\prime} 57^{\prime \prime}$ & $83^{\circ} 54^{\prime} 04^{\prime \prime}$ & 743.00 & 331.50 \\
\hline 4 & Srisailam & Andhra Pradesh & Krishna & $16^{\circ} 05^{\prime} 12^{\prime \prime}$ & $78^{\circ} 53^{\prime} 49^{\prime \prime}$ & 616.42 & 1670.00 \\
\hline 5 & Ukai & Gujarat & Tapi & $21^{\circ} 14^{\prime} 03^{\prime \prime}$ & $73^{\circ} 34^{\prime} 42^{\prime \prime}$ & 600.95 & 300.00 \\
\hline 6 & Almatti & Karnataka & Krishna & $16^{\circ} 20^{\prime} 42^{\prime \prime}$ & $75^{\circ} 54^{\prime} 04^{\prime \prime}$ & 487.87 & 290.00 \\
\hline 7 & Rihand & Uttar Pradesh & Rihand & $24^{\circ} 12^{\prime} 11^{\prime \prime}$ & $83^{\circ} 00^{\prime} 22^{\prime \prime}$ & 468.00 & 300.00 \\
\hline 8 & Sriram Sagar & Telangana & Godavari & $18^{\circ} 58^{\prime} 00^{\prime \prime}$ & $78^{\circ} 20^{\prime} 00^{\prime \prime}$ & 450.82 & 27.00 \\
\hline 9 & Jayakwadi & Maharashtra & Godavari & $19^{\circ} 28^{\prime} 30^{\prime \prime}$ & $75^{\circ} 23^{\prime} 08^{\prime \prime}$ & 398.00 & 12.00 \\
\hline 10 & Rengali & Odisha & Brahmani & $21^{\circ} 15^{\prime} 49^{\prime \prime}$ & $85^{\circ} 01^{\prime} 12^{\prime \prime}$ & 378.40 & 250.00 \\
\hline 11 & Tungabhadra & Karnataka & Tungabhadra & $15^{\circ} 15^{\prime} 47^{\prime \prime}$ & $76^{\circ} 19^{\prime} 54^{\prime \prime}$ & 349.20 & 36.00 \\
\hline 12 & Sardar Sarovar & Gujarat & Narmada & $21^{\circ} 49^{\prime} 49^{\prime \prime}$ & $73^{\circ} 44^{\prime} 54^{\prime \prime}$ & 348.67 & 1450.00 \\
\hline 13 & Linganamakki & Karnataka & Sharavati & $14^{\circ} 10^{\prime} 33^{\prime \prime}$ & $74^{\circ} 50^{\prime} 47^{\prime \prime}$ & 317.28 & 55.00 \\
\hline 14 & Nagarjuna Sagar & Telangana & Krishna & $16^{\circ} 34^{\prime} 33^{\prime \prime}$ & $79^{\circ} 18^{\prime} 44^{\prime \prime}$ & 284.90 & 815.00 \\
\hline 15 & Maharana Pratap Sagar & Himachal Pradesh & Beas & $31^{\circ} 58^{\prime} 15^{\prime \prime}$ & $75^{\circ} 56^{\prime} 45^{\prime \prime}$ & 260.00 & 396.00 \\
\hline 16 & Rana Pratap Sagar & Rajasthan & Chambal & $24^{\circ} 55^{\prime} 04^{\prime \prime}$ & $75^{\circ} 34^{\prime} 52^{\prime \prime}$ & 198.29 & 172.00 \\
\hline 17 & Hasdeo Bango & Chhattisgarh & Hasdeo & $22^{\circ} 39^{\prime} 28^{\prime \prime}$ & $82^{\circ} 39^{\prime} 00^{\prime \prime}$ & 188.47 & 120.00 \\
\hline 18 & Chandil & Jharkhand & Subarnarekha & $22^{\circ} 58^{\prime} 27^{\prime \prime}$ & $86^{\circ} 01^{\prime} 08^{\prime \prime}$ & 174.09 & 130.00 \\
\hline 19 & Gobind Sagar & Himachal Pradesh & Sutlej & $31^{\circ} 24^{\prime} 42^{\prime \prime}$ & $76^{\circ} 25^{\prime} 58^{\prime \prime}$ & 168.35 & 1325.00 \\
\hline 20 & Mettur & Tamil Nadu & Cauvery & $11^{\circ} 48^{\prime} 12^{\prime \prime}$ & $77^{\circ} 48^{\prime} 23^{\prime \prime}$ & 153.46 & 250.00 \\
\hline
\end{tabular}

covering the water surface of the reservoirs with PV panels. Reservoirs located in 13 different states of India with a water surface area greater than $100 \mathrm{~km}^{2}$ were selected for the study. The details of the selected reservoirs are listed in Table 3. The reservoirs are not selected based on the incoming irradiation levels of the location since the irradiation level across India is fair enough for power generation from the solar PV system throughout the year. The location of each selected reservoir is shown in Fig. 2. The water surface area of the selected reservoirs ranges from 153.46 to $2453 \mathrm{~km}^{2}$, and the hydropower generation capacity of the reservoir varies from MW to GW levels.

Rajghat reservoir is the largest reservoir in India located in Uttar Pradesh on Betwa River, and the Rihand reservoir has the HEPP plant with a large hydropower capacity in the country. Indira Sagar dam has the secondlargest reservoir with 1000 MW HEPP located in Madhya Pradesh. Srisailam dam on the river Krishna in Andhra Pradesh, Sardar Sarovar dam on river Narmada in Gujarat, and Bhakra dam (Gobind Sagar reservoir) on river Sutlej in Himachal Pradesh also have HEPP plants with a high capacity of more than $1000 \mathrm{MW}$. Ukai reservoir is the second-largest reservoir in Gujarat next to Sardar Sarovar, constructed on the river Tapi. Hirakud reservoir is the third-largest reservoir in Odisha with historic values like Asia's largest artificial lake and India's first multipurpose dam after its independence. Rengali reservoir is located in from Odisha, with the water surface area half that of Hirakud. Karnataka holds the three largest reservoirs, namely Almatti, Tungabhadra, and Linganamakki in river Krishna, Tungabhadra, and Sharavati.

Sriram Sagar reservoir on the river Godavari is the lifeline of the larger part of Telangana state. Apart from irrigation and power production, the reservoir also aids in flood control. Jayakwadi reservoir is also constructed on the same river in Maharashtra with the lowest HEPP capacity among the HEPPs in the selected dams. Nagarjuna Sagar dam stands between Andhra Pradesh and Telangana, and it is the world's largest and highest masonry dam. It is the primary source of irrigation and drinking to urban cities of the state. Maharana Pratap Sagar, situated in the foothills of Himalaya on the Beas River, is the crucial fishing reservoir of Himachal Pradesh. It is also declared as Ramsar Wetland site due to its rich waterfowl diversity. Gobind Sagar reservoir is also located on Himachal Pradesh and Punjab border. It is the second tallest dam in Asia and the highest straight gravity dam in India serving water for irrigation to Punjab, Haryana, Himachal Pradesh, and Rajasthan (Jain et al. 2007).

Hasdeo Bango reservoir on Hasdeo River is the first multipurpose water project in Chhattisgarh with three units of $40 \mathrm{MW}$ capacity of HEPPs. Chandil reservoir is a multipurpose project in Jharkhand located on the river Subarnarekha. Finally, the Mettur reservoir on river 


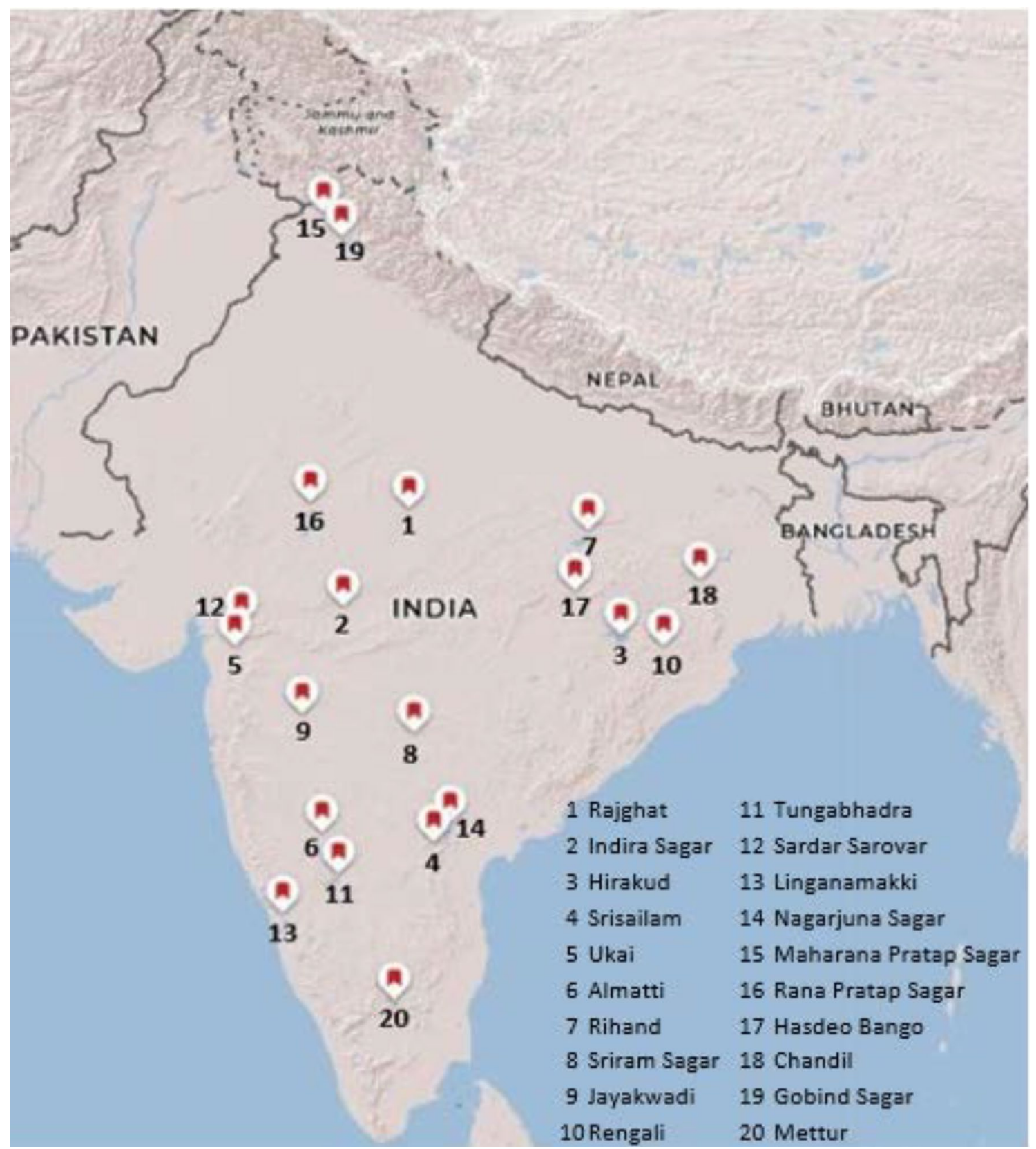

Fig. 2 Location of selected reservoirs in India

Cauvery of Tamil Nadu is the identified spot of the state government to implement its first floating PV of $100 \mathrm{MW}$ capacity. All these selected reservoirs are the major source of freshwater for agriculture, industrial, and domestic purposes. Thus, implementing FPV system will enhance their serving purpose in a better way by reducing evaporation. Further, the integration of FPV with the inbuilt HEPPs will result in increased renewable power production.

\section{Preliminary design and numerical modeling of FPV plants}

For all the selected dams, a model FPV plant was primarily designed with a nameplate DC capacity of $5 \mathrm{MW}$, and the simulation was performed using the software HelioScope (Helioscope 2020). The metrological data in the form of the typical metrological year (TMY) format, which includes irradiation, temperature, wind velocity, and albedo of the reservoir, were collected from the NASA database from 2000 to 2020 (NASA(POWER) 
2020). These data sets were used to estimate the power generation of the FPV systems by reasonably sizing the annual dataset with hourly meteorological values over a period. Along with these data, the additional information required for the numerical analysis includes: (i) sun path data to estimate the solar surface angle required to calculate the plane of array (POA) and total collector irradiation (UO-SRML 2019) and (ii) horizon data of the FPV system obtained from Photovoltaic Geographical Information System (PVGIS) to estimate the shading and reflection loss due to trees and hills. The annual global horizontal irradiation (GHI) and the plane-of-array (POA) irradiation were calculated using the transposition model for the selected locations. Since the PV panels are placed at an optimum tilt angle from the horizontal surface, the transposition model converts the irradiation data incident on the horizontal surface to the surface inclined at a required angle. The diffused radiation on the PV panels inclined at any angle was calculated using the Hays model (McArthur and Hay 1978). Albedo coefficient, a measure of the irradiance reflected by the PV panel was calculated using the reflected radiation on the titled PV module. Literature states that the albedo coefficient for the water reservoirs in India varies from 0.19 to 0.19 (Mani et al. 1975).

In the preliminary design of the model FPV system, Trina solar TSM-PD14 $(320 \mathrm{~W})$ type polycrystalline PV panels were considered. The panels were supported on pontoons made up of high-density polyethylene (HDPE). The height and row spacing of the HDPE pontoons were assumed to be $0.5 \mathrm{~m}$. Each pontoon will accompany a pair of PV modules. Pontoons were interconnected to form a row of PV arrays. The spacing between each row of PV panels was taken as $0.15 \mathrm{~m}$ to provide a catwalk for the operation and maintenance of PV panels. Submerged or floating cables were considered to connect the FPV array with the substation. In the FPV system, the substation with central inverters is either floating type when the array is away from the shore or grounded type when the array is close to the land.

The major factors responsible for the maximum output power are the direction and position of the FPV array. Since India is located in the northern hemisphere, the PV modules should be placed in due south direction with a collector azimuth angle equal to $180^{\circ}$ (Stine and Geyer 2001). The horizon data of the south-faced FPV systems in the selected reservoirs were obtained from PVGIS to arrive at the optimum horizon height. The suitable alignment of FPV panels facing solar azimuth angle corresponding to the respective lower horizon height will help reduce the shading losses in the FPV plants.

The position of the FPV array in any reservoir depends on the mooring and anchoring feasibility, access to grid connection, and other external disturbances (Chandrasekaran and Nagavinothini 2018, 2019). In integrated FPV-HEPP systems, the distance of the FPV system from the HEPP substation is one of the major factors that determine the location of the FPV system to minimize the resistance loss of connecting wires. The location of the FPV systems in the selected reservoirs was selected, considered all these factors into account. The position of the 5-MW model FPV system in Rajghat reservoir and Indira Sagar reservoir is shown in Fig. 3. In the Rajghat reservoir, the FPV array is positioned near the reservoir bank. In this position, one side of the FPV array can be bank-anchored where the edges of the array can be connected using nylon or chain ropes, while the other side can be pile-anchored using concrete blocks placed at the bottom of the water body. FPV array being away from the bank of India Sagar reservoir, the entire system can be held in position using pile anchoring system.

The soiling losses in FPV systems are comparatively lesser than that of land-based PV systems, and the soiling factors for the FPV systems were assumed in the range of $1-2 \%$. A constant derate factor of $0.5 \%$ was assumed to minimize the losses associated with the AC system. The module DC nameplate was calculated using the number of modules used in the FPV plant and the maximum power of the PV panel at nominal operating cell temperature conditions (irradiance $=800 \mathrm{~W} / \mathrm{m}^{2}$; wind velocity $=1 \mathrm{~m} / \mathrm{s}$; cell temperature $=20^{\circ} \mathrm{C}$ ). Then, the maximum potential power of the PV array was calculated using the total collector irradiance and the PV power output. The energy transmitted to the grid was then calculated using the maximum potential power of the PV array. The manufacturing
Fig. 3 Location of 5-MW model FPV system in a Rajghat reservoir and $\mathbf{b}$ Indira Sagar reservoir (a)

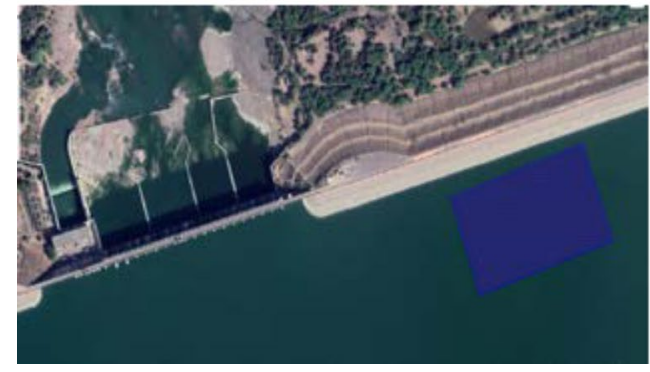

(b)

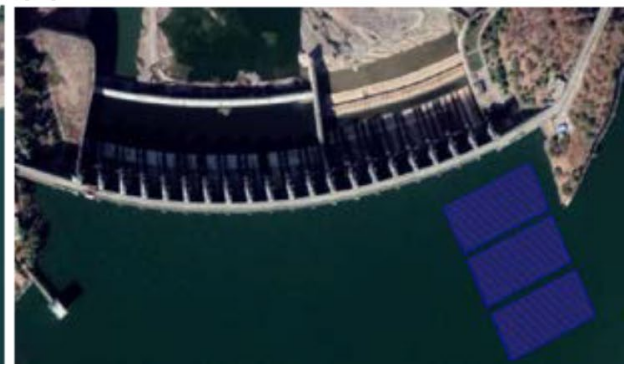


(a)

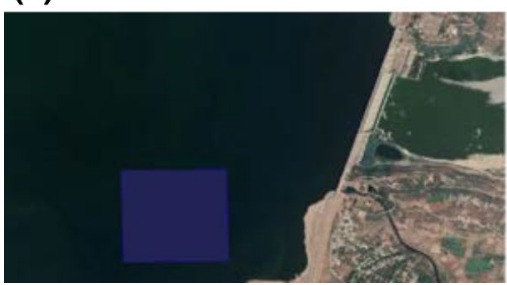

(b)

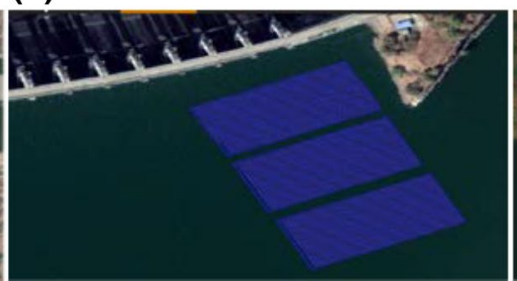

(c)

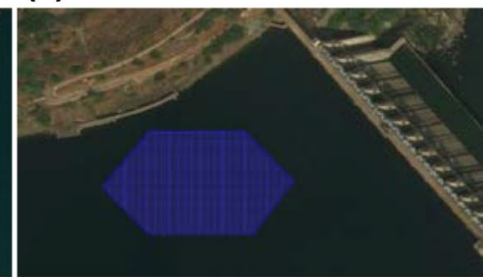

Fig. 4 Shape and position of FPV array in a Nagarjuna reservoir and $\mathbf{b}$ Indira Sagar reservoir and $\mathbf{c}$ Srisailam reservoir

tolerance of the PV module was assumed to be uniformly distributed, with the module range varying from $-2.50 \%$ to $+2.50 \%$.

Another important aspect in the design of the FPV array is the shape of the FPV system. The shape of the system should be selected based on the shape of the water body, water level during off monsoon seasons, and the drag forces on the FPV system. Thus, square, rectangular, and circular FPV array systems were suitably selected for the reservoirs considered in the study. The different shapes of the FPV systems considered in the present study for Nagarjuna Sagar, Indira Sagar, and Srisailam reservoirs are shown in Fig. 4. The size of the single FPV array was decided considering the negative impacts of wind and wave action. Even though the adverse effect of wind and wave forces on FPV systems located in reservoirs is considerably low compared to that of offshore locations, these factors need to be considered to avoid mooring failure of the systems under extreme conditions due to natural calamities (Chandrasekaran and Nagavinothini 2020; Nagavinothini and Chandrasekaran 2019). To this end, the FPV plant can be designed as a single large system (Fig. 4a, c), or it may be divided into several small parts of the FPV array (Fig. 4b).

The power output obtained from the numerical model of the FPV systems developed in the present study is identified to be in a similar range to the power output from the existing FPV systems in India. However, a direct comparison of results is not possible due to the variation in

\section{Results and discussion}

\section{Power generation from model FPV plants}

The optimum tilt angle $(\beta)$ of the PV panels was selected by numerical analyses of the model FPV plant by varying the tilt angle from flat $\left(0^{\circ}\right)$ to vertical position $\left(89^{\circ}\right)$. It was found that the tilt angle of $10^{\circ}$ to $20^{\circ}$ had resulted in maximum power generation due to higher POA irradiance. Further, a variation in the power generation capacity of the FPV plants at different reservoirs was also observed due to the variation in the solar irradiation levels at the selected locations. The varying shape of the FPV array at different reservoirs also tends to modify the total area required for the 5-MW FPV plant considered in the study. The total area of the FPV model plant ranges from 43,272.51 to $44,988.4 \mathrm{~m}^{2}$, with an average area of $44,330.56 \mathrm{~m}^{2}$.

The electrical performance of the FPV plants with optimum tilt angle at selected reservoirs is listed in Table 4. As seen from the results, the installation of 5-MW FPV plants at 20 reservoirs will result in an annual energy yield of $159.64 \mathrm{GW}$. The energy harvesting capacity of the FPV plant changes following the intensity and duration of the irradiation levels of the location. High energy density is observed in the model FPV system in the Sardar Sarovar reservoir. Followed by the energy yield, the performance ratio (PR) and specific yield $(k W h / k W)$ of the FPV system were also studied. The performance ratio of the FPV system is calculated using the following expression (Helioscope 2020):

$$
\text { Performence rattio }(P R)=\frac{\text { Energy supplied to the grid }(k W h)}{\text { Total power output of the PVsystem }(k W) \times \frac{\text { POA Irradiance }\left(\frac{k W}{m^{2}}\right)}{\text { STC Irradiannce }\left(\frac{k W}{m^{2}}\right)}}
$$

the type of the PV panels used in the FPV systems and the non-availability of onsite experimental data. Based on the reasonable assumptions on the major parameters used in the assessment of electrical performance, the numerical model tends to provide acceptable accuracy.
PR of $75 \%$ and above is achieved in all the selected reservoirs, with a maximum value of $80.30 \%$ in Mettur reservoir, Tamil Nadu. The specific yield $(\mathrm{kWh} / \mathrm{kW})$ of the system is the ratio of energy yield to the installed capacity of the FPV system. The specific yield value of the FPV systems in the selected 20 reservoirs ranges from 


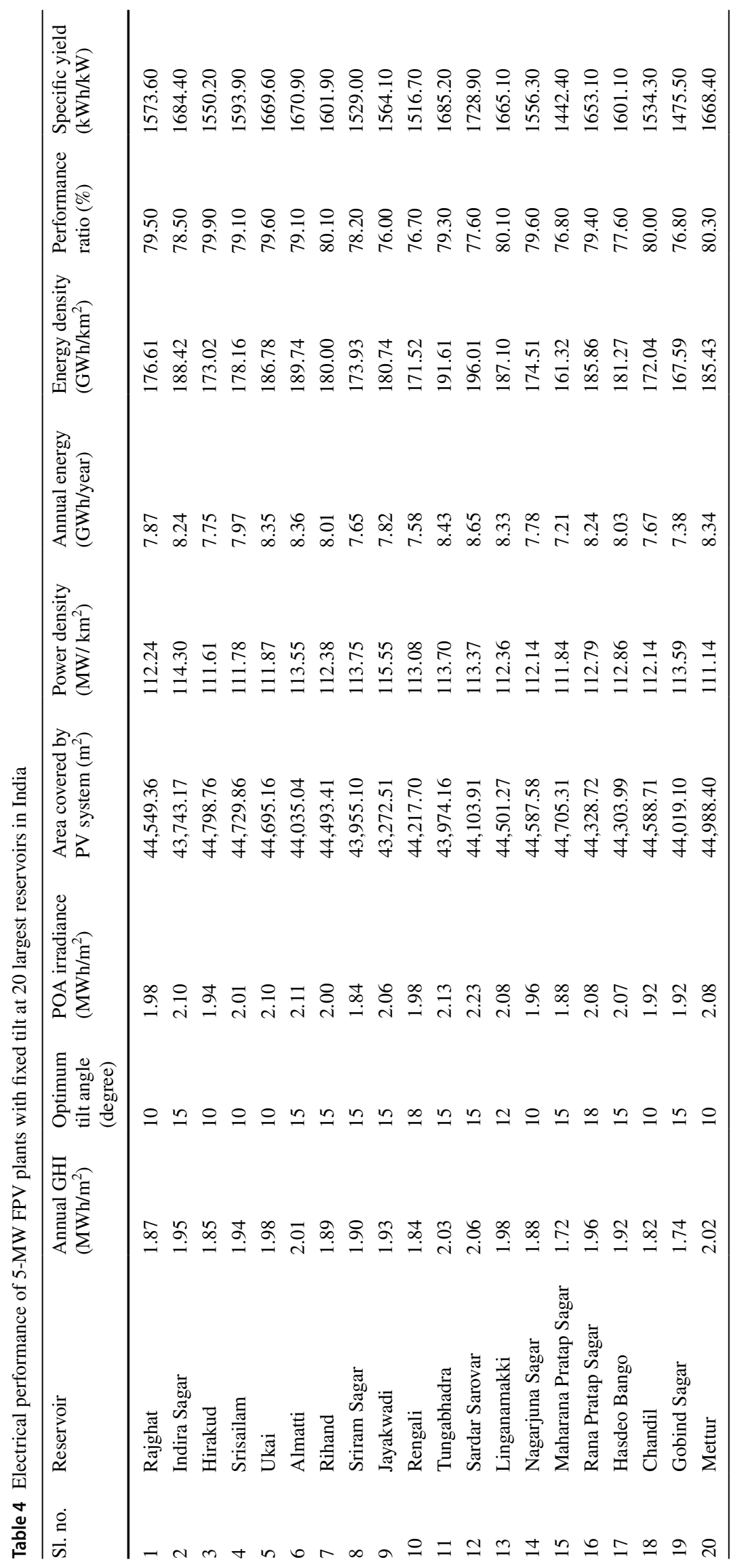


1442.40 to $1728.80 \mathrm{kWh} / \mathrm{kW}$, with the maximum value in the Sardar Sarovar dam.

The average power density of the existing FPV plants all over the world accounts for $99.23 \mathrm{MWp} / \mathrm{km}^{2}$ (Liu et al. 2017). The power density of the proposed FPV plants in the present study ranged from 111 to $116 \mathrm{MWp} / \mathrm{km}^{2}$, with an average value of $112.8 \mathrm{MWp} / \mathrm{km}^{2}$. This shows the advantage of implementing the FPV plants in Indian reservoirs. Further, the average power density of the land-based PV system is $70 \mathrm{MW} / \mathrm{km}^{2}$ (Cazzaniga et al. 2019). Thus, the proposed FPV plants in Indian reservoirs will result in a $38 \%$ gain in power generated per $\mathrm{km}^{2}$. In addition, FPV plants with tracking systems will further increase the annual energy density compared to that of fixed mount FPV plants.

\section{Land- and water-saving effect}

The average area required for a 5-MW FPV plant was identified as $44,330 \mathrm{~m}^{2}$ based on the preliminary design of FPV systems in the selected reservoirs. The total area
Fig. 5 Linear increase in annual evaporation rate in Indian reservoirs from 2000 to 2019

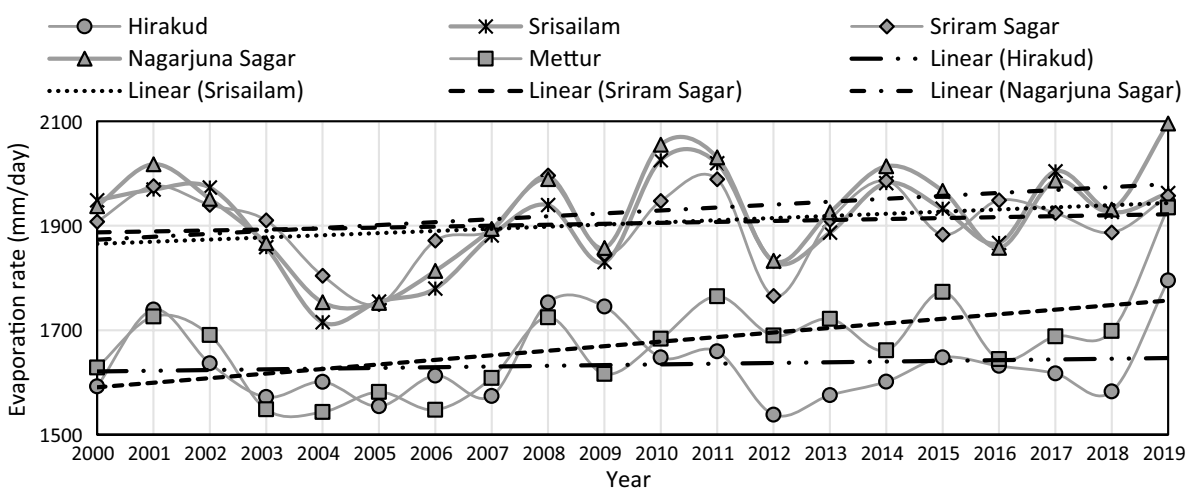

Table 5 Water-saving effect of FPCS on reservoirs with HEPP

\begin{tabular}{|c|c|c|c|c|c|c|c|c|}
\hline S1. no. & Reservoir & $\begin{array}{l}\text { Average yearly } \\
\text { evaporation rate } \\
\text { (mm/year) }\end{array}$ & $\begin{array}{l}\text { Direct water } \\
\text { saving }\left(\times 10^{6} \mathrm{~m}^{3} /\right. \\
\text { year })\end{array}$ & $\begin{array}{l}\text { Increase in } \\
\text { hydro power } \\
(\mathrm{MWh})\end{array}$ & $\begin{array}{l}\text { Percentage } \\
\text { increase in hydro } \\
\text { power }\end{array}$ & $\begin{array}{l}\text { Indirect } \\
\text { water sav- } \\
\text { ing } \\
\left(\times 10^{6} \mathrm{~m}^{3} /\right. \\
\text { year })\end{array}$ & $\begin{array}{l}\text { Area ratio } \\
\mathrm{S}_{\mathrm{H}} / \mathrm{S}_{\mathrm{F}}\end{array}$ & $\begin{array}{l}\text { Energy } \\
\text { ratio } \mathrm{E}_{\mathrm{FPV}} / \\
\mathrm{E}_{\mathrm{H}}\end{array}$ \\
\hline 1 & Rajghat & 1488.70 & 0.059 & 10.91 & 5.82 & 43.06 & 0.002 & 11.51 \\
\hline 2 & Indira Sagar & 1943.70 & 0.077 & 29.37 & 0.42 & 21.47 & 0.005 & 0.33 \\
\hline 3 & Hirakud & 1633.91 & 0.066 & 16.75 & 0.73 & 30.48 & 0.006 & 0.93 \\
\hline 4 & Srisailam & 1919.43 & 0.077 & 46.74 & 2.00 & 13.17 & 0.007 & 0.93 \\
\hline 5 & Ukai & 1886.65 & 0.076 & 21.71 & 1.60 & 29.18 & 0.007 & 1.68 \\
\hline 6 & Almatti & 1990.66 & 0.079 & 17.19 & 1.51 & 38.34 & 0.009 & 2.02 \\
\hline 7 & Rihand & 1737.76 & 0.070 & 26.55 & 1.40 & 20.99 & 0.010 & 1.16 \\
\hline 8 & Sriram Sagar & 1914.64 & 0.076 & 13.59 & 10.06 & 42.61 & 0.010 & 15.51 \\
\hline 9 & Jayakwadi & 1920.38 & 0.075 & 12.89 & 20.56 & 45.39 & 0.011 & 34.19 \\
\hline 10 & Rengali & 1527.98 & 0.061 & 17.88 & 0.87 & 25.79 & 0.012 & 1.02 \\
\hline 11 & Tungabhadra & 1946.15 & 0.077 & 15.86 & 4.82 & 40.89 & 0.013 & 7.01 \\
\hline 12 & Sardar Sarovar & 1917.63 & 0.076 & 51.76 & 1.16 & 12.71 & 0.013 & 0.53 \\
\hline 13 & Linganamakki & 1477.66 & 0.059 & 15.12 & 2.65 & 32.58 & 0.014 & 4.00 \\
\hline 14 & Nagarjuna Sagar & 1936.48 & 0.078 & 40.41 & 2.62 & 14.96 & 0.016 & 1.38 \\
\hline 15 & $\begin{array}{l}\text { Maharana Pratap } \\
\text { Sagar }\end{array}$ & 1704.62 & 0.069 & 38.06 & 0.86 & 13.00 & 0.017 & 0.44 \\
\hline 16 & Rana Pratap Sagar & 1937.79 & 0.077 & 17.40 & 1.55 & 36.60 & 0.022 & 2.01 \\
\hline 17 & Hasdeo Bango & 1647.35 & 0.066 & 23.85 & 3.46 & 22.13 & 0.024 & 3.19 \\
\hline 18 & Chandil & 1531.27 & 0.061 & 14.56 & 4.60 & 32.37 & 0.026 & 6.64 \\
\hline 19 & Gobind Sagar & 1756.73 & 0.070 & 65.62 & 0.45 & 07.82 & 0.026 & 0.14 \\
\hline 20 & Mettur & 1683.80 & 0.068 & 18.55 & 1.81 & 30.65 & 0.029 & 2.23 \\
\hline
\end{tabular}


covered by the FPV plants in the 20 selected reservoirs is around $886,591.22 \mathrm{~m}^{2}$, which corresponds to the saving of $0.9 \mathrm{~km}^{2}$ of land. The actual average evaporation rate in the selected reservoirs was calculated by the Penman-Monteith method using the NASA meteorological data collected from 2000 to 2019 (NASA(POWER) 2020). Despite the requirement of a large dataset, the Penman-Monteith method tends to provide accurate evaporation values compared to other methods reported in the literature (Allen et al. 1998; Zarei et al. 2015). The maximum evaporation rate was observed in the reservoirs during 2016 and 2019. In particular, maximum evaporation rates of about 1980.66, 1943.71, and $1931.15 \mathrm{~mm} /$ day are observed in Indira Sagar, Almatti, and Tungabhadra reservoirs. The evaporation in the reservoirs varies from 1472.66 to $1980.66 \mathrm{~mm} /$ day. Further, a linear increase in the evaporation rate was obtained from Hirakud, Srisailam, Sriram Sagar, Nagarjuna Sagar, and Mettur reservoir, as shown in Fig. 5. This shows the chances of a further increase in evaporation in the fore coming years. It also highlights the necessity to avoid evaporation loss and preserve water for domestic and irrigation purposes in major Indian reservoirs.

The PET per year was then averaged for the considered duration to estimate the volume of water saved through evaporation mitigation. An evaporation prevention ratio of 0.9 was assumed for the HDPE pontoon considered in the model FPV plant. The evaporation rate at the selected locations and amount of water saved are listed in Table 5. The results indicate that the installation of $20 \mathrm{FPV}$ plants in the Indian reservoirs will result in saving 1.40 million cubic meters of water per day. This corresponds to the direct water-saving effect of the FPV covering systems. If this saved water is used for hydropower generation, the HEPPs in the reservoirs will generate additional energy of $514.80 \mathrm{MWh} /$ day in total. From the selected reservoirs, the maximum additional hydropower generation was obtained from the Bhakra dam (Gobind Sagar reservoir).

The term indirect water-saving refers to the amount of water consumed by the hydropower plant, which is obtained from converting the electricity generated from the FPV system to the volume of water. It is calculated using the following equation (Liu et al. 2017):

$V_{e}=\frac{0.75 * 3600 * E_{P V} *[1-\varepsilon]}{\rho * g * \Delta H}$

where $E_{P V}$ is the total amount of electricity generated by the FPV plant (Wh), $\varepsilon$ is the discarding rate of PV power, $\rho$ is the density of the water $\left(\mathrm{kg} / \mathrm{m}^{3}\right), g$ is the acceleration due to gravity $\left(\mathrm{m} / \mathrm{s}^{2}\right)$, and $\Delta H$ is the water head $(\mathrm{m})$. Based on this, FPV systems in 20 reservoirs will lead to indirect water savings of 554.2 million cubic meters every year. In addition to the power generation and evaporation mitigation advantages of the FPV covering systems, the smaller area ratio (ratio of the area of FPV system $\left(\mathrm{S}_{\mathrm{F}}\right)$ to the total water surface area of the reservoir $\left(\mathrm{S}_{\mathrm{H}}\right)$ corresponding to each reservoir shows that this structural system on the water surface will not affect the ecosystem. Thus, the proposed system is highly efficient in producing environmentally sound renewable power. The energy ratio (ratio of FPV to HEPP- $\mathrm{E}_{\mathrm{FPV}} / \mathrm{E}_{\mathrm{H}}$ ) results reveal that the FPV systems with smaller coverage areas can produce higher energy than HEPPs in 14 selected reservoirs.

The additional advantage of the FPV system is the cooling effect provided by the water surface to the PV panels. In this context, the FPV systems indirectly save the water used for panel cooling and cleaning purposes for the groundmounted or roof-mounted PV systems (Gorjian et al. 2020; Zahedi et al. 2021). The evaporation rate mitigation in the water body is proportional to the area of the FPV system. Studies state that the pontoon-based floating covering system on water bodies effectively reduces the evaporation rate by $90 \%$ (Ferror-Gisbert et al. 2013). However, the water loss through evaporation cannot be eliminated since complete covering of the reservoir may adversely affect the water ecosystem. The exact effects of the FPV system on water quality and biodiversity are still under study. Hence, it is advisable to cover less than $30 \%$ of the reservoir to avoid its negative impacts on the water quality and ecosystem (Hass et al. 2020).

\section{FPV model plants with a single-axis tracking mechanism}

FPV panels with single- or dual-axis tracking mechanisms will help in maximizing the solar output. Studies reveal that an FPV system with a tracking mechanism increases the electric energy harvest even up to $25 \%$ compared to a fixed mount system (Cazzaniga et al. 2019; Grubišić-Čabo et al. 2016; Nagananthini et al. 2019). Recent innovation and advancements in tracker technology aid in the installation and effective operation of tracking mechanisms even in uneven terrain and challenging weather conditions. With the continuous improvement in tracker technology, a $45 \%$ increase in implementation is expected in the global market from 2022 to 2025 .

In the present study, the FPV plants on Indian reservoirs were also analyzed with a single-axis tracking system to compare the electrical performance of the systems with and without tracking. In single-axis tracking, the azimuth angle becomes the axis of rotation, and this results in the direction shift of the PV panel following the sun path. The inclusion of a tracking mechanism increases the POA irradiance of the FPV system up to $13 \%$, which in turn increases the annual energy generated from the system up to $11 \%$. Among the selected reservoirs, Sardar Sarovar 
Fig. 6 Comparison of POA irradiance levels in fixed and single-axis tracking mechanisms: a Sardar Sarovar reservoir and b Maharana Pratap Sagar reservoir

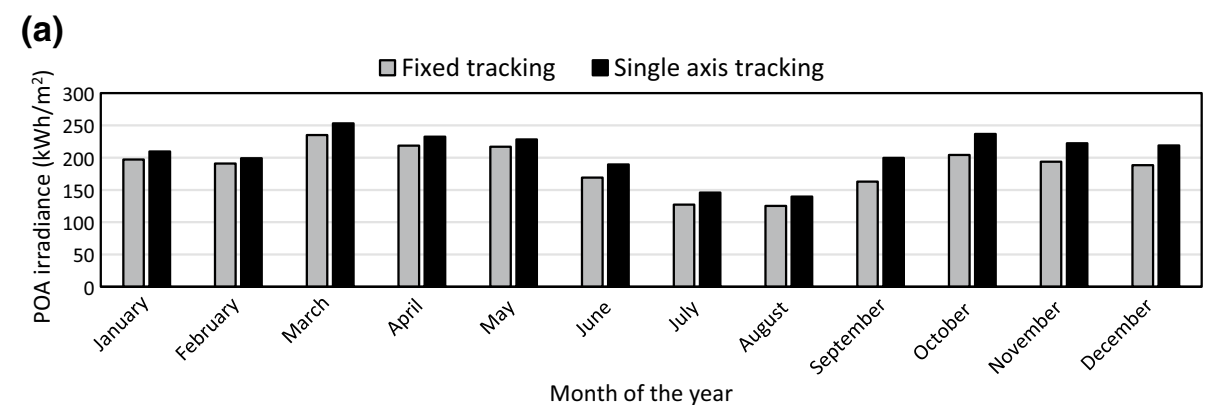

(b)
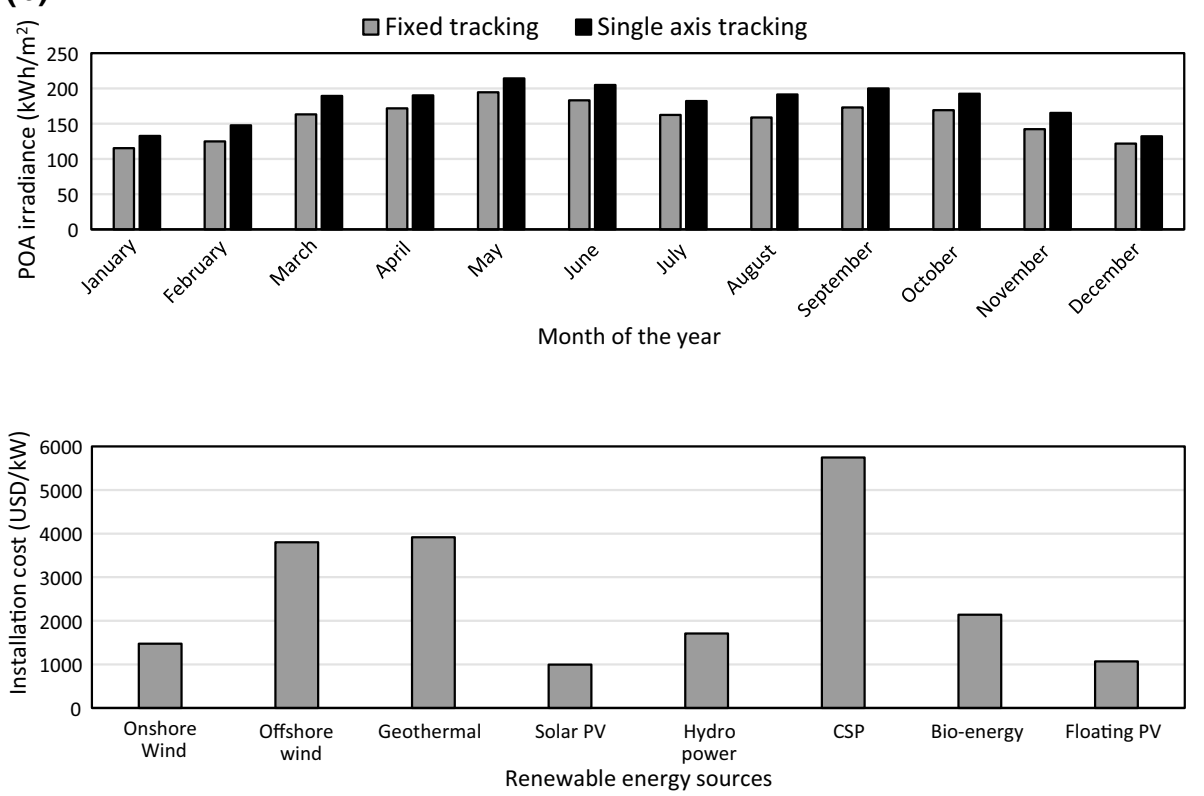

Fig. 7 Comparison of the installation cost of renewable energy resources (IRENA 2019).

*CSP-Concentrated Solar Power shares the largest portion of the FPV system cost. The complete setup including transport and assembly of the floating platform is $0.08 \mathrm{USD} / \mathrm{m}^{2}$, and the total cost of the floating system, including mooring and anchoring mechanism, is $0.76 \mathrm{USD} / \mathrm{Wp}$. By adding the cost of PV panels and other electrical components, which is about $0.618 \mathrm{USD} / \mathrm{Wp}$, the total cost of the FPV system without tracking system in the Indian reservoirs of 5-MW capacity is $1.378 \mathrm{USD} / \mathrm{Wp}$. It is also found that the cost of the tracking mechanisms increases the total cost of the FPV plant by $11.30 \%$.

\section{Carbon footprint analysis}

The per capita $\mathrm{CO}_{2}$ emission in India is equal to 1.60 tons, which is the third-largest carbonaceous emission from fossil fuels globally. According to the United Nations report (2016), about half of the nation's toxic carbon emission is from the power generation, transmission, and distribution sector (IEA/IRENA 2018). In this context, the power generation through solar PV systems would increase to 162 GW by the year 2021 and the average $\mathrm{CO}_{2}$ emission factor is expected to reduce from $0.721 \mathrm{~kg} \mathrm{CO}_{2} / \mathrm{kWh}$ (reported 
Table 6 Carbon footprint analysis of FPV systems with and without tracking

\begin{tabular}{|c|c|c|c|c|c|c|c|}
\hline \multirow[t]{2}{*}{ Sl. no. } & \multirow[t]{2}{*}{ Reservoir } & \multirow[t]{2}{*}{$\begin{array}{l}\text { Specific emission } \\
\left(\mathrm{CO}_{2} / \mathrm{MWh}\right)\end{array}$} & \multicolumn{2}{|c|}{$\begin{array}{l}\mathrm{CO}_{2} \text { saving from } \mathrm{FPV} \text { power } \\
\text { generation (tons } \mathrm{CO}_{2} \text { /year) }\end{array}$} & \multirow[t]{2}{*}{$\begin{array}{l}\mathrm{CO}_{2} \text { saving from evapo- } \\
\text { ration (tons } \mathrm{CO}_{2} \text { /year) }\end{array}$} & \multicolumn{2}{|c|}{$\begin{array}{l}\text { Total } \mathrm{CO}_{2} \text { saving (tons } \\
\mathrm{CO}_{2} \text { /year) }\end{array}$} \\
\hline & & & Fixed mount & $\begin{array}{l}\text { Single-axis } \\
\text { tracking }\end{array}$ & & Fixed mount & $\begin{array}{l}\text { Single-axis } \\
\text { tracking }\end{array}$ \\
\hline 1 & Rajghat & 1.46 & 229.75 & 247.59 & 1.25 & 230.99 & 248.83 \\
\hline 2 & Indira Sagar & 0.89 & 146.71 & 149.61 & 1.60 & 148.31 & 151.21 \\
\hline 3 & Hirakud & 0.97 & 150.37 & 157.22 & 1.38 & 151.75 & 158.59 \\
\hline 4 & Srisailam & 1.00 & 159.38 & 166.90 & 1.61 & 160.99 & 168.51 \\
\hline 5 & Ukai & 1.10 & 183.66 & 190.26 & 1.59 & 185.24 & 191.84 \\
\hline 6 & Almatti & 1.07 & 178.80 & 184.60 & 1.65 & 180.45 & 186.25 \\
\hline 7 & Rihand & 0.96 & 153.77 & 158.88 & 1.45 & 155.23 & 160.33 \\
\hline 8 & Sriram Sagar & 0.95 & 145.26 & 153.52 & 1.58 & 146.84 & 155.10 \\
\hline 9 & Jayakwadi & 0.93 & 145.47 & 150.29 & 1.56 & 147.03 & 151.85 \\
\hline 10 & Rengali & 0.97 & 147.13 & 153.01 & 1.27 & 148.40 & 154.28 \\
\hline 11 & Tungabhadra & 1.07 & 180.32 & 187.04 & 1.61 & 181.92 & 188.64 \\
\hline 12 & Sardar Sarovar & 0.93 & 160.80 & 166.71 & 1.59 & 162.39 & 168.30 \\
\hline 13 & Linganamakki & 1.07 & 178.18 & 184.87 & 1.24 & 179.41 & 186.11 \\
\hline 14 & Nagarjuna Sagar & 0.95 & 147.84 & 153.90 & 1.62 & 149.46 & 155.52 \\
\hline 15 & Maharana Pratap Sagar & 1.10 & 158.66 & 165.13 & 1.43 & 160.10 & 166.57 \\
\hline 16 & Rana Pratap Sagar & 1.05 & 173.02 & 176.34 & 1.62 & 174.63 & 177.95 \\
\hline 17 & Hasdeo Bango & 0.96 & 154.20 & 158.71 & 1.37 & 155.57 & 160.08 \\
\hline 18 & Chandil & 1.07 & 164.16 & 168.78 & 1.28 & 165.44 & 170.07 \\
\hline 19 & Gobind Sagar & 1.10 & 162.29 & 166.54 & 1.45 & 163.75 & 167.99 \\
\hline 20 & Mettur & 1.07 & 178.52 & 186.76 & 1.42 & 179.94 & 188.18 \\
\hline
\end{tabular}

in 2016) to $0.604 \mathrm{~kg} \mathrm{CO}_{2} / \mathrm{kWh}$ in 2022 through renewable power generation (CEA 2019). The country needs more attention in expanding renewable power generation to minimize the use of existing coal power plants. The $\mathrm{CO}_{2}$ savings for the FPV systems in the selected reservoirs are listed in Table 6. Specific electricity consumption is used to estimate the $\mathrm{CO}_{2}$ saving from evaporation mitigation. The average amount of water saved through evaporation mitigation by the FPV systems is $70795.11 \mathrm{~m}^{3} /$ year, which saves $29,791.72$ tons of $\mathrm{CO}_{2}$. The total $\mathrm{CO}_{2}$ saving by the FPV systems with fixed tracking is $3.3 \mathrm{Mt} \mathrm{CO}_{2}$, and it is 4.78\% lesser than the single-axis tracking FPV system.

In the case of total carbon emission from the FPV system, the significant contribution can be attributed to the manufacturing process of $\mathrm{PV}$ panels and floating pontoon systems. However, it is $20 \%$ less than that coal-powered electricity sources (IEA 2021). Recent innovations and research are aimed at further reducing the carbon emission from solar panels. One such novel technology is the solar panel made from two mineral layers called perovskite (Wagner et al. 2020). Sustainable floating PV structures that can be recycled or developed from the recycled products include the future scope of the study to reduce carbon emission.

\section{Conclusion}

The present study investigates the performance of FPV technology in Indian reservoirs with HEPP. Implementing these innovative FPV systems on reservoirs not only generates solar power but also helps in reducing water loss due to evaporation and carbon emission. The saved water can also be conveniently used to increase hydropower generation. Numerical analyses of a preliminarily designed 5-MW FPV plant in the 20 largest reservoirs in India were carried out. The electrical performance of the model plant, along with its environmental and economic benefits, was studied. The results show that the implementation of these 20 model FPV plants in Indian reservoirs will generate $159.64 \mathrm{GWh}$ of power annually. The power produced per $\mathrm{km}^{2}$ from these fixed tracking PV systems was $38 \%$ more efficient than the land-based PV system. Further, the FPV system with a single-axis tracking mechanism results in a $3.65 \%$ gain in energy density than the fixed mount FPV system.

Eventually, the FPV plants acting as a covering system for reservoirs help save 1.40 million cubic meters of water every year. The saved water can be effectively used to produce additional hydropower. The implementation of this renewable technology will also avoid 3.30 million tons 
of $\mathrm{CO}_{2}$ emissions annually. Altogether, this hybrid FPVHEPP technology helps increase the renewable power production in the nation without affecting the environment. The results of this detailed investigation highlight the suitability of Indian reservoirs for FPV implementation. With a large number of reservoirs and open water bodies all over the country, this sustainable technology is the most suitable solution to meet the energy requirement and water crisis in India. With the identified advantages of innovative hybrid technology, the future research by the research group is focused on detailed operation simulation of the hybrid FPV-HEPP systems, static and dynamic interconnection topologies, and DC-DC converter configurations.

Acknowledgements The authors did not receive any funding for conducting the study and to assist with the preparation of the manuscript.

Funding Open access funding provided by Università degli Studi di Napoli Federico II within the CRUI-CARE Agreement.

\section{Declarations}

Conflict of interest The authors have no conflicts of interest to declare that are relevant to the content of the article.

Human and animal rights This manuscript does not contain any studies with human participants or animals performed by any of the authors.

Informed consent Informed consent was obtained from all the participants included in the study.

Open Access This article is licensed under a Creative Commons Attribution 4.0 International License, which permits use, sharing, adaptation, distribution and reproduction in any medium or format, as long as you give appropriate credit to the original author(s) and the source, provide a link to the Creative Commons licence, and indicate if changes were made. The images or other third party material in this article are included in the article's Creative Commons licence, unless indicated otherwise in a credit line to the material. If material is not included in the article's Creative Commons licence and your intended use is not permitted by statutory regulation or exceeds the permitted use, you will need to obtain permission directly from the copyright holder. To view a copy of this licence, visit http://creativecommons.org/licenses/by/4.0/.

\section{References}

Acharya M, Devraj S (2019) Floating Solar Photovoltaic (FSPV): A Third Pillar to Solar PV Sector. TERI Discussion Paper: Output of the ETC India Project. The Energy and Resources Institute, New Delhi

Allen RG, Pereira LS, Raes D, Smith M (1998) Crop evapotranspiration-guidelines for computing crop water requirements-FAO Irrigation and drainage paper 56. Fao, Rome 300(9):D05109
Azami S, Vahdaty M, Torabi F (2017) Theoretical analysis of reservoir-based floating photovoltaic plant for 15-khordad dam in Delijan. Energy Equipment Syst 5(2):211-218. https://doi.org/ 10.22059/EES.2017.25760

Cazzaniga R, Cicu M, Rosa-Clot M, Rosa-Clot P, Tina GM, Ventura C (2018) Floating photovoltaic plants: Performance analysis and design solutions. Renew Sustain Energy Rev 81:1730 1741. https://doi.org/10.1016/j.rser.2017.05.269

Cazzaniga R, Rosa-Clot M, Rosa-Clot P, Tina GM (2019) Integration of PV floating with hydroelectric power plants. Heliyon 5(6):e01918. https://doi.org/10.1016/j.heliyon.2019.e01918Get

Cazzaniga, R., 2020. Floating PV Structures. In Floating PV Plants (pp. 33-45). Academic Press. https://doi.org/10.1016/B978-012-817061-8.00004-X

CEA, 2019. Central Electricity Authority, Thermal Performance evaluation and climate change division - other reports CDM $\mathrm{CO}_{2}$ Baseline database, Version 15.0. https://cea.nic.in/wpcontent/uploads/baseline/2020/07/user_guide_ver15.pdf

Chandrasekaran S, Nagavinothini R (2018) Tether analyses of offshore triceratops under wind, wave and current. Marine Syst Ocean Technol 13(1):34-42. https://doi.org/10.1007/ s40868-018-0043-9

Chandrasekaran S, Nagavinothini R (2019) Tether analyses of offshore triceratops under ice force due to continuous crushing. Innov Infrastruct Solutions 4(1):25. https://doi.org/10.1007/ s41062-019-0212-5

Chandrasekaran S, Nagavinothini R (2020) Offshore Compliant Platforms: Analysis, Design, and Experimental Studies. John Wiley \& Sons

Craig, I., Green, A., Scobie, M. and Schmidt, E., 2005. Controlling evaporation loss from water storages. National Centre for Engineering in Agricultural Publication 1000581/1, USQ, Toowoomba.

Farfan J, Breyer C (2018) Combining floating solar photovoltaic power plants and hydropower reservoirs: a virtual battery of great global potential. Energy Procedia 155:403-411. https:// doi.org/10.1016/j.egypro.2018.11.038

Ferrer-Gisbert C, Ferrán-Gozálvez JJ, Redón-Santafé M, Ferrer-Gisbert P, Sánchez-Romero FJ, Torregrosa-Soler JB (2013) A new photovoltaic floating cover system for water reservoirs. Renew Energy 60:63-70. https://doi.org/10.1016/j.renene.2013.04.007

Gorjian S, Sharon H, Ebadi H, Kant K, Scavo FB, Tina GM (2020) Recent technical advancements, economics and environmental impacts of floating photovoltaic solar energy conversion systems. J Cleaner Producti. https://doi.org/10.1016/j.jclepro.2020. 124285

Grubišić-Čabo F, Nižetić S, Giuseppe Marco T (2016) Photovoltaic panels: a review of the cooling techniques. Trans FAMENA 40(S1-1):63-74

Gulagi A, Choudhary P, Bogdanov D, Breyer C (2017) Electricity system based on $100 \%$ renewable energy for India and SAARC. PLoS ONE 12(7):e0180611. https://doi.org/10.1371/journal. pone. 0180611

Haas J, Khalighi J, de la Fuente A, Gerbersdorf SU, Nowak W, Chen PJ (2020) Floating photovoltaic plants: ecological impacts versus hydropower operation flexibility. Energy Convers Manage 206:112414. https://doi.org/10.1016/j.enconman.2019.112414

Helioscope solar design software, 2020 Folsom Labs [Available online]. https://help.helioscope.com/collection/ 295-system-design

IEA, 2021. India Energy Outlook 2021, International Energy Agency [Available online]. https://www.iea.org/reports/india-energyoutlook-2021. Accessed 15 March 2021

IEA/IRENA, 2018. Renewable policies database [Available online]. https://www.iea.org/policies/4916-jawaharlal-nehru-natio 
nal-solar-mission-phase-i-ii-and-iii . Accessed 07 September 2020

IRENA, 2019. Renewable Energy Statistics 2019, The International Renewable Energy Agency, Abu Dhabi [Available online].https://www.irena.org/publications/2019/Jul/Renew able-energy-statistics-2019. Accessed 07 September 2020

Jain A, Mehta R, Mittal SK (2011) Modeling impact of solar radiation on site selection for solar PV power plants in India. Int J Green Energy 8(4):486-498. https://doi.org/10.1080/15435 075.2011.576293

Jain, S.K., Agarwal, P.K. and Singh, V.P., 2007. Hydrology and water resources of India (Vol. 57). Springer Science \& Business Media

Kougias I, Bódis K, Jäger-Waldau A, Moner-Girona M, MonfortiFerrario F, Ossenbrink H, Szabó S (2016) The potential of water infrastructure to accommodate solar PV systems in Mediterranean islands. Sol Energy 136:174-182. https://doi.org/10. 1016/j.solener.2016.07.003

Krishnan, R., Sanjay, J., Gnanaseelan, C., Mujumdar, M., Kulkarni, A. and Chakraborty, S., 2020. Assessment of climate change over the Indian region: a report of the ministry of earth sciences (MOES), government of India (p. 226). Springer Nature

Lee N, Grunwald U, Rosenlieb E, Mirletz H, Aznar A, Spencer R, Cox S (2020) Hybrid floating solar photovoltaics-hydropower systems: benefits and global assessment of technical potential. Renew Energy 162:1415-1427. https://doi.org/10.1016/j. renene.2020.08.080

Liu L, Wang Q, Lin H, Li H, Sun Q (2017) Power generation efficiency and prospects of floating photovoltaic systems. Energy Procedia 105:1136-1142. https://doi.org/10.1016/j.egypro. 2017.03.483

Lopes MPC, de Andrade Neto S, Branco DAC, de Freitas MAV, da Silva Fidelis N (2020) Water-energy nexus: Floating photovoltaic systems promoting water security and energy generation in the semiarid region of Brazil. J Clean Prod 273:122010. https:// doi.org/10.1016/j.jclepro.2020.122010

Mani A, Chacko O, Desikan V, Vijayan G (1975) Aircraft measurements of the earth's Albedo over India. Indian J Radio Space Phys 4:304-309

McArthur LB, Hay JE (1978) On the anisotropy of diffuse solar radiation. Bull Am Meteor Soc 59:1442-1443

Mckay, A., 2013. Floatovoltaics: Quantifying the Benefits of a Hydro - Solar Power Fusion. Pomona Senior Theses, 74

Mittal, D., Saxena, B.K. and Rao, K.V.S., 2017, August. Potential of floating photovoltaic system for energy generation and reduction of water evaporation at four different lakes in Rajasthan. In 2017 International Conference On Smart Technologies For Smart Nation (SmartTechCon) (pp. 238-243). IEEE. doi: https://doi.org/10.1109/SmartTechCon.2017.8358376

MNRE, 2019. Ministry of new renewable energy, Solar, 2019 [Online], Available - https://mnre.gov.in/solar/current-status/ Accessed 20.1.2021

Murdock, H.E., Gibb, D., Andre, T., Sawin, J.L., Brown, A., Ranalder, L., Collier, U., Dent, C., Epp, B., Hareesh Kumar, C. and Joubert, F., 2021. Renewables 2021-Global status report (INISFR--21-0788). France

Nagananthini, R. and Nagavinothini, R., 2021. Investigation on floating photovoltaic covering system in rural Indian reservoir to minimize evaporation loss. Int J Sustain Energy, pp.1-25. https://doi.org/10.1080/14786451.2020.1870975

Nagananthini, R., Nithya, G. and Bhuvanesh, S., 2019, April. Economic Analysis of Bi-Directional Net-meters with Orientation and Positioning of Solar Module. In 2019 International Conference on Advances in Computing and Communication Engineering (ICACCE) (pp. 1-5). IEEE. doi: https://doi.org/10.1109/ ICACCE46606.2019.9079961
Nagananthini, R., Nagavinothini, R. and Balamurugan, P., 2020. Floating Photovoltaic Thin Film Technology-A Review. In Intelligent Manufacturing and Energy Sustainability (pp. 329338). Springer, Singapore. https://doi.org/10.1007/978-981-151616-0_32

Nagavinothini, R. and Chandrasekaran, S., 2019, August. Dynamic analyses of offshore triceratops in ultra-deep waters under wind, wave, and current. In Structures (Vol. 20, pp. 279-289). Elsevier. https://doi.org/10.1016/j.istruc.2019.04.009

NASA Prediction of Worldwide Energy Resource (POWER), 2020 [Available online]. https://power.larc.nasa.gov

Nazififard, M.O.H.A.M.M.A.D., Taheri, S.M. and Nazififardarani, K., 2017, February. Novel floating photo voltaic cover systems generating electricity and prevent evaporative losses for agriculture industry in Iran. In The third international energy management and technology conference, Shahid Beheshti University, Tehran (pp. 28-29)

Panneerselvam B, Paramasivam SK, Karuppannan S, Ravichandran N, Selvaraj P (2020) A GIS-based evaluation of hydrochemical characterisation of groundwater in hard rock region, South Tamil Nadu. India Arabian J Geosci 13(17):1-22. https://doi. org/10.1007/s12517-020-05813-w

Panneerselvam B, Muniraj K, Thomas M, Ravichandran N, Bidorn B (2021) Identifying influencing groundwater parameter on human health associate with irrigation indices using the Automatic Linear Model (ALM) in a semi-arid region in India. Environ Res. https://doi.org/10.1016/j.envres.2021.111778

Penman, H.L., 1948. Natural evaporation from open water, bare soil and grass. Proc Royal Soc London. Series A. Math Phys Sci, 193(1032), pp.120-145. https://doi.org/10.1098/rspa.1948. 0037

Ranjbaran P, Yousefi H, Gharehpetian GB, Astaraei FR (2019) A review on floating photovoltaic (FPV) power generation units. Renew Sustain Energy Rev 110:332-347. https://doi.org/10. 1016/j.rser.2019.05.015

Rao, B.B., Sandeep, V.M., Rao, V.U.M. and Venkateswarlu, B., 2012. Potential Evapotranspiration estimation for Indian conditions: Improving accuracy through calibration coefficients. Tech. Bull. No 1/2012. All India Co-ordinated research Project on Agrometeorology, Central Research Institute for Dryland Agriculture, Hyderabad. 60p

Ravichandran N, Ravichandran N, Panneerselvam B (2021) Performance analysis of a floating photovoltaic covering system in an Indian reservoir. Clean Energy 5(2):208-228. https://doi.org/ 10.1093/ce/zkab006

Rosa-Clot M, Tina GM, Nizetic S (2017) Floating photovoltaic plants and wastewater basins: an Australian project. Energy Procedia 134:664-674. https://doi.org/10.1016/j.egypro.2017. 09.585

Rosa-Clot, M. and Tina, G.M., 2020. Integration of PV Floating With Hydroelectric Power Plants (HPPs). In Floating PV Plants (pp. 89-100). Academic Press. https://doi.org/10.1016/B978-012-817061-8.00008-7

Sahu A, Yadav N, Sudhakar K (2016) Floating photovoltaic power plant: A review. Renew Sustain Energy Rev 66:815-824. https://doi.org/10.1016/j.rser.2016.08.051

Santafé MR, Soler JBT, Romero FJS, Gisbert PSF, Gozálvez JJF, Gisbert CMF (2014) Theoretical and experimental analysis of a floating photovoltaic cover for water irrigation reservoirs. Energy 67:246-255. https://doi.org/10.1016/j.energy.2014.01. 083

Stine, W. B., and M. Geyer. 2001. Power from the sun [Available online]. https://www.powerfromthesun.net/

Taboada ME, Cáceres L, Graber TA, Galleguillos HR, Cabeza LF, Rojas R (2017) Solar water heating system and photovoltaic 
floating cover to reduce evaporation: experimental results and modeling. Renew Energy 105:601-615. https://doi.org/10. 1016/j.renene.2016.12.094

TERI, 2018. Climate Policy Initiate, Energy transitions commission, India [Available online]. http://www.teriin.org/sites/defau 1t/files/files/etc-key-messages-summary.pdf

Trapani K, Millar DL (2013) Proposing offshore photovoltaic (PV) technology to the energy mix of the Maltese islands. Energy Convers Manage 67:18-26. https://doi.org/10.1016/j.enconman. 2012.10.022

Trapani K, Redón Santafé M (2015) A review of floating photovoltaic installations: 2007-2013. Prog Photovoltaics Res Appl 23(4):524-532. https://doi.org/10.1002/pip.2466

UO-SRML, 2019. University of Oregon-Solar radiation monitoring laboratory [Available online]. http://solardat.uoregon.edu/ SunChartProgram.html
Wagner L, Mastroianni S, Hinsch A (2020) Reverse manufacturing enables perovskite photovoltaics to reach the carbon footprint limit of a glass substrate. Joule 4(4):882-901. https://doi.org/ 10.1016/j.joule.2020.02.001

Zahedi R, Ranjbaran P, Gharehpetian GB, Mohammadi F, Ahmadiahangar R (2021) Cleaning of floating photovoltaic systems: a critical review on approaches from technical and economic perspectives. Energies 14(7):2018. https://doi.org/10.3390/ en 14072018

Zarei AR, Zare S, Parsamehr AH (2015) Comparison of several methods to estimate reference evapotranspiration. West African J Appl Ecol 23(2):17-25 